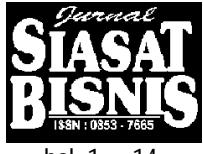

\title{
PENDEKATAN GROUNDED THEORY UNTUK MEMAHAMI STRATEGI PEMERINTAH DAERAH ISTIMEWA YOGYAKARTA DALAM MENGHADAPI ERA OTONOMI DAERAH DAN GLOBALISASI
}

\author{
Fathul Himam, Bagus Riyono \& Sumaryono \\ Fakultas Psikologi \\ Universitas Gadjah Mada Yogyakarta
}

\begin{abstract}
This grounded theory research approach was directed to understand how Pemerintah Daerah developed its strategic process in dealing with local autonomy and globalization, both on the organizational level and individual level. Indepth interview was applied to 14 high level Pemerintah Daerah Officials. It was directed to understand their experiences in managing changing situations. The results showed that there were six major themes: (1) empowering the society; (2) restructuring the organization; (3) improving management system; (4) economic development; (5) developing the human resources; and (6) shifting the mindset. Reanalyzing these themes by using selective and axial coding, it was found that there were two emerging major functions of the strategy, i.e.(1) Maintaining the system; (2) adapting to environmental demands.
\end{abstract}

Keywords: grounded theory, open coding, selective coding, axial coding, themes, strategy.

Perkembangan mutakhir sebagai dampak dari otonomisasi daerah dan derasnya pengaruh arus globalisasi adalah makin dekatnya hubungan antara kebutuhan masyarakat dengan kebijakan serta hasil kerja Pemerintah Daerah (Pemda) untuk memenuhinya. Pemda dituntut untuk selalu peka terhadap perkembangan kebutuhan masyarakat. Hasil kerja yang berkualitas tinggi serta sesuai dengan kebutuhan nyata masyarakat merupakan indikator keberhasilan yang perlu direalisasikan oleh Pemda.

Masalahnya adalah tuntutan serta kebutuhan masyarakat terhadap kinerja organisasi cenderung selalu berubah. Kualitas yang tinggi dan memuaskan pada hari ini belum tentu merupakan hal yang sama untuk periode waktu yang akan datang. Akibatnya, organisasi akan selalu dituntut untuk mampu menerapkan strategi yang tepat dan up to date, yang mampu mengakomodasi secara efektif situasi yang berubah itu (Carnevale, 1991; Das, 1995; Himam, 1996, 2002).

Dengan menggarisbawahi kompleksitas pengembangan strategi organisasi, terasa diperlukan satu pemahaman yang mendasar dan mendalam mengenai proses serta arah strategi yang dikembangkan oleh suatu organisasi. Tema ini merupakan tema sentral yang banyak menarik perhatian peneliti (DiBella, 1993; Van de ven \& Poole, 1995; Nevis, et.al., 
1995; Herscovitch \& Meyer, 2002). Ke arah proses pemahaman inilah penelitian ini akan dilakukan.

Untuk menjelaskan proses pengembangan strategi yang diterapkan oleh organisasi dalam menghadapi situasi yang serba berubah (eg. otonomisasi daerah, globalisasi, perkembangan teknologi informasi, dan lain-lain), bukanlah merupakan hal yang mudah dan sederhana. Banyak teoretisi dan praktisi yang masih mengalami kesulitan dalam mengembangkan konsep-konsep yang tepat untuk menjelaskan proses tersebut (Van de ven \& Poole, 1995; Clute, et.al., 1999).

Pada era Revolusi Industri, situasi di atas bisa dijelaskan melalui otomatisasi dan standardisasi proses kerja. Otomatisasi dipandang sebagai panacea untuk meningkatkan kinerja organisasi (Stickland, 1998). Hanya saja, era globalisasi memaksa konsep itu tidak lagi relevan untuk diterapkan. Organisasi mulai dituntut untuk tidak lagi product oriented, tapi harus mulai berorientasi pada service yang sesuai dengan perkembangan kebutuhan masyarakat (Lazlo \& Laugel, 2000). Oleh karenanya, proses pemahaman terhadap strategi apa yang paling efektif untuk menangani situasi yang berubah itu terus berkembang (Gowing, et.al., 1998; Cady \& Hardalupas, 1999).

Masalahnya, upaya-upaya pemahaman tersebut malah menciptakan variasi-variasi model dan konsep yang mengarah pada pluralisme teori yang seringkali membingungkan para praktisi dalam mengaplikasikannya pada dunia nyata (Van de Ven \& poole, 1995). Situasi ini potensial mengarah pada kompartementalisasi dalam memahami gejala yang sama, sehingga sulit untuk menemukan benang merah yang menghubungkan keterkaitan antara satu model atau konsep dengan model-model yang lain. Akibatnya jelas, proses pengembangan strategi yang didasarkan pada satu model pemahaman seringkali tidak menghasilkan kinerja yang diharapkan.

Dengan memahami arah permasalahan tersebut, penelitian ini tidaklah ditujukan untuk menambah kompleksitas atau kompartementalisasi pemahaman terhadap proses pengembangan strategi organisasi dalam menghadapi situasi yang berubah itu. Penelitian ini lebih diarahkan pada upaya untuk mengeksplorasi dikembangkannya pemahaman-pemahaman baru yang sifatnya kontekstual yang melatarbelakangi fenomena yang diteliti.

Penelitian ini diharapkan mempunyai sumbangan yang positif bagi upaya pengembangan model teoretis yang bisa digunakan untuk memahami proses yang dikembangkan oleh satu organisasi dalam menghadapi situasi yang serba berubah. Secara praktis diharapkan hasil penelitian ini bisa dijadikan dasar untuk merumuskan rekomendasi-rekomendasi yang sifatnya research-based bagi upaya pengembangan efektivitas strategi organisasi. 
Upaya untuk memahami proses pengembangan strategi organisasi memerlukan pendekatan yang sifatnya holistic, yang mengaitkan misi organisasi dengan tuntutan lingkungan. Untuk itu maka diperlukan pendekatan yang sifatnya kualitatif yang mampu merekonstruksi keseluruhan proses yang terjadi.

Pendekatan yang sifatnya kuantitatif kurang tepat untuk digunakan karena: (1) sangat sulit untuk menentukan dan mengidentifikasi variabelvariabel apa yang terlibat dalam proses pengembangan strategi karena fenomena ini sifatnya context bound. Artinya, lingkungan dan dimensinya haruslah difahami secara mendalam untuk bisa memahami strategi organisasi (Bogdan \& Biklen, 1992; Stake, 1995); (2) fenomena strategi merupakan suatu proses yang memerlukan pemahaman yang sifatnya holistic dan multi-dimensional. Pendekatan kuantitatif tidak didesain untuk mengkaji gejala penelitian semacam ini (Creswell, 2002).

Atas dasar pemahaman tersebut maka jelaslah bahwa penelitian ini tidak diarahkan pada upaya pembuktian teori atau hipotesis, namun ditujukan untuk menjawab satu pertanyaan besar yaitu: strategi organisasi atau individual apakah yang dikembangkan Pemda dan para aparatnya dalam menghadapi era otonomi daerah dan globalisasi?

\section{METODE PENELITIAN}

Penelitian ini difokuskan pada upaya menghasilkan teori yang bisa digunakan untuk memahami konteks pengembangan strategi organisasi. Karenanya, pendekatan Grounded Theory sangatlah tepat untuk digunakan. Pendekatan ini berfungsi untuk memahami gejala yang sifatnya: (1) merupakan suatu proses, yang cenderung berubah dari waktu ke waktu; (2) goal oriented, yang terjadi secara terencana dan diarahkan pada pencapaian tujuan tertentu; dan (3) melibatkan intervening conditions yang memfasilitasi munculnya gejala yang diteliti (Strauss dan Corbin, 1990).

Grounded Theory pada dasarnya merupakan proses yang sifatnya siklikal yang diarahkan pada upaya menyusun satu model teoretis atas dasar pengalaman serta proses belajar partisipan yang diteliti. Untuk itu diperlukan adanya proses pengumpulan data dan analisis data yang sifatnya berkesinambungan sampai diperoleh dasar informasi yang cukup untuk memunculkan satu teori. Informasi-informasi tersebut dikumpulkan melalui metode wawancara yang mendalam, yang mengungkap secara komprehensif persepsi dan pengalaman individu dalam mengembangkan strategi organisasi dalam menghadapi otonomi daerah ini.

Bahan dan alat. Bahan yang digunakan dalam penelitian ini adalah panduan wawancara yang pada pokoknya menanyakan tentang bagaimana Pemda mengembangkan strategi dalam menghadapi era 
otonomi daerah dan globalisasi. Alat yang dipergunakan dalam penelitian ini adalah tape recorder untuk merekam wawancara.

Prosedur pelaksanaan. Untuk mewakili pemerintah daerah DIY, diambil subjek atau partisipan penelitian dari kebupaten Sleman dan Kodya Yogyakarta. Tim peneliti, yang terdiri dari tiga orang peneliti dan satu orang asisten, menghadap sekretaris daerah untuk minta ijin melakukan wawancara dengan beberapa staf yang terkait dengan perumusan kebijakan otonomi daerah. Kesulitan yang dihadapi adalah untuk mencari waktu untuk wawancara. Beberapa kali wawancara gagal karena pada waktu yang sudah dijanjikan ternyata beberapa di antara mereka ada acara atau tugas lain yang mendadak dan tidak bisa ditinggalkan. Oleh karena itu beberapa wawancara mengalami penjadwalan ulang. Jumlah pejabat Pemda yang berhasil diwawancara ada 15 orang.

\section{HASIL DAN PEMBAHASAN}

Dengan menggunakan teknik open coding (Strauss \& Corbin, 1990; Creswell, 1996), hasil wawancara diurai, diperbandingkan antara satu dengan yang lain, dan dicari kategori-kategori yang mampu digunakan untuk menjelaskan fenomena strategi Pemerintah Daerah Istimewa Yogyakarta (Pemda) dalam menghadapi era otonomisasi daerah (otda) dan arus globalisasi. Transkripsi hasil wawancara digunakan sebagai data yang dianalisis.

Pengalaman para partisipan penelitian dapat dikelompokkan dalam dua kategori besar, yaitu: (a) strategi pada tingkat organisasi; dan (b) strategi pada tingkat individual (lihat Tabel I: Tema Umum Strategi Pemda dalam Menghadapi Era Otonomisasi Daerah dan Arus Globalisasi). Masing-masing kategori kemudian diurai ke dalam tema-tema umum yang meliputi: (a) strategi organisasi: pemberdayaan masyarakat, restrukturisasi, perbaikan sistem manajemen, dan pengembangan perekonomian; (b) strategi individual: peningkatan kualitas sumberdaya manusia (SDM) dan perubahan mindset. 
Tabel 1. Tema Umum Strategi Pemda dalam Menghadapi Era Otonomisasi Daerah dan Arus Globalisasi

\begin{tabular}{|c|c|c|c|}
\hline $\begin{array}{l}\text { Klasifikasi } \\
\text { Umum }\end{array}$ & Kategori & Indikator & Contoh \\
\hline \multirow[t]{6}{*}{$\begin{array}{l}\text { Strategi } \\
\text { Organisasi }\end{array}$} & $\begin{array}{l}\text { 1. Pemberdayaan } \\
\text { Masyarakat }\end{array}$ & $\begin{array}{ll} & \text { Partisipasi } \\
\square & \text { Kepercayaan } \\
\square & \text { Jalur komunikasi } \\
\square & \text { Kemitraan }\end{array}$ & $\begin{array}{ll} & \text { Partisipasi } \\
\square & \text { Dana kembali ke masyarakat } \\
\square & \text { Variasi akses komunikasi } \\
\square & \text { Pemberian hak, peningkatan peran, } \\
& \text { enterpreneurship }\end{array}$ \\
\hline & 2. Restrukturisasi & $\begin{array}{ll} & \text { Regrouping } \\
\square & \text { Efisiensi }\end{array}$ & $\begin{array}{ll} & \text { Koordinasi antar bidang serumpun } \\
\square & \text { Layanan terpadu } \\
\square & \text { Span of control yang kecil } \\
\square & \text { Perampingan, kaya fungi-miskin } \\
& \text { struktur, sistem DataBase } \\
\end{array}$ \\
\hline & $\begin{array}{l}\text { 3. Perbaikan sistem } \\
\text { manajemen }\end{array}$ & 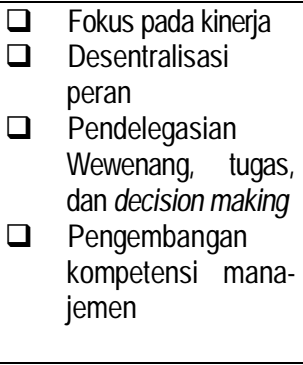 & $\begin{array}{l}\text { Penyelenggaraan berbasis kinerja, } \\
\text { anggaran berbasis kinerja } \\
\square \quad \begin{array}{l}\text { Pemberdayaan institusi lokal } \\
\text { (kecamatan, kelurahan) }\end{array} \\
\text { Memacu kecamatan dan kelu- } \\
\text { rahan melakukan kewenangan } \\
\text { Membangun kepemimpinan yang } \\
\text { mampu memperhatikan aspirasi } \\
\text { profesionalisme dan gugus kendali } \\
\text { mutu }\end{array}$ \\
\hline & $\begin{array}{l}\text { 4. } \begin{array}{l}\text { Pengembangan } \\
\text { perekonomian }\end{array}\end{array}$ & $\begin{array}{l}\text { Penanaman modal } \\
\text { lokal dan asing }\end{array}$ & $\begin{array}{l}\text { Pengembangan parivisata sebagai } \\
\text { daerah percontohan }\end{array}$ \\
\hline & $\begin{array}{l}\text { 5. Pengembangan } \\
\text { SDM }\end{array}$ & $\begin{array}{ll}\square & \text { Pengembangan } \\
& \text { kompetensi teknologi } \\
\square & \text { Pengembangan biro- } \\
\text { krasi }\end{array}$ & $\begin{array}{ll}\square & \text { Kursus singkat komputer, internet, } \\
\text { jaringan } \\
\square & \\
\square & \text { Keleluasaan dalam mengembang- } \\
\text { kan wewenang }\end{array}$ \\
\hline & 6. Perubahan mindset & $\begin{array}{ll}\square & \text { Enterpreneurship } \\
\square & \text { Mengikis mental biro- } \\
& \text { krat } \\
\square & \text { Pengembangan visi } \\
& \text { yang sama } \\
\square & \text { Penerimaan terhadap } \\
\text { perubahan }\end{array}$ & $\begin{array}{l}\square \text { Pengembangan karakter jiwa wira- } \\
\text { usaha, mandiri } \\
\text { Mengikis kebanggaan memiliki } \\
\text { anak buah. Anak buah dan fasilitas } \\
\text { seharusnya untuk melayani } \\
\text { masyarakat, bukan pribadi } \\
\text { Mengembangkan staf untuk } \\
\text { mendukung visi, pimpinan sebagai } \\
\text { lokomotif, dan gerbong harus se- } \\
\text { jalan dengan lokomotif. } \\
\text { Keterbukaan informasi, mengem- } \\
\text { bangkan perasaan satu tim, ber- } \\
\text { usaha melibatkan orang berda- } \\
\text { sarkan kompetensi }\end{array}$ \\
\hline
\end{tabular}




\section{Pemberdayaan Masyarakat}

Salah seorang partisipan penelitian mengatakan, "Otonomi itu kan maksudnya pemberdayaan masyarakat, tapi sebetulnya arah pemberdayaan masyarakat itu seperti apa?"

Ungkapan ini merefleksikan bagaimana Pemda sebagai satu organisasi berusaha menerjemahkan arah kinerjanya pada era otonomi daerah ini. Untuk bisa otonom, maka masyarakat harus diberdayakan.

Terdapat beberapa upaya yang berkaitan dengan pemberdayaan masyarakat, yaitu: (1) pengembangan partisipasi masyarakat. Artinya masyarakat diberi keleluasaan untuk berkiprah, terlibat, dan bekerja sama. $\mathrm{Hal}$ ini berbeda dengan era sebelum otda berlaku. Pada era ini masyarakat lebih banyak pasif dan bersikap nrimo; (2) membangun kepercayaan, yang antara lain dilakukan dengan menggunakan dana yang terhimpun untuk dikembalikan pada masyarakat, guna mendanai program-program yang sesuai dengan kebutuhan mereka; (3) membuka jalur informasi dan komunikasi dengan cara memberikan variasi akses untuk berkomunikasi langsung dengan Pemda (misal: melalui jalur hotline, Short Message System (SMS), dan lain-lain); dan (4) membina dan meningkatkan kemandirian masyarakat. Kemandirian dalam hal ini antara lain dikembangkan melalui peningkatan peran dan hak untuk berwirausaha.

\section{Restrukturisasi}

Restrukturisasi diarahkan pada upaya peningkatan efisiensi serta koordinasi yang efektif antar bagian-bagian yang ada dalam organisasi Pemda. Upaya ini dapat berujud mempersempit span of control dari seorang pejabat. Pengelompokkan bidang-bidang kerja yang sejenis sehingga struktur kerja menjadi ramping (diistilahkan "kaya fungsi miskin struktur"), serta pengembangan data base system (misalkan untuk informasi kepegawaian) juga merupakan ujud efisiensi yang perlu dilakukan.

Melalui upaya restrukturisasi ini, diharapkan fungsi-fungsi kerja yang ada dapat lebih diberdayakan sehingga benar-benar mampu mencerminkan kebutuhan kerja riil dari Pemda. Seperti dikatakan oleh seorang partisipan, "(Struktur) dirampingkan, dengan membuat kecil dulu. Kalau memang tantangan ke depan kita menjadi besar, yang akan kita kembangkan".

\section{Perbaikan Sistem Manajemen}

Perbaikan sistem manajemen pada era otda dikonsentrasikan pada beberapa strategi pokok, yitu: (1) memfokuskan sistem manajemen yang berorientasi pada kinerja; (2) pendelegasian wewenang dan desentralisasi peran; serta (3) pengembangan kompetensi manajerial.

Dengan acuan pada upaya memberdayakan masyarakat, manajemen yang berbasis kinerja terasa sangat penting untuk dikembangkan. 
Kinerja yang riil akan merupakan dasar untuk mengevaluasi apakah sistem manajemen yang dikembangkan mampu mencapai sasaran atau tidak. Hal ini berdampak luas pada pemberian reward maupun pada proses penilaian prestasi. Reward harus dikaitkan dengan kinerja agar pegawai termotivasi untuk bekerja secara sungguh-sungguh dan terarah. Ditambah dengan penilaian prestasi yang berbasis kinerja, maka secara langsung Pemda sedang berupaya untuk mengembangkan kompetensi manajerial maupun kompetensi yang lain yang relevan dengan proses kerja dari para pekerjanya. Profesionalisme, kepemimpinan yang aspiratif merupakan beberapa contoh kinerja yang diharapkan bisa dikembangkan lebih jauh.

Pendelegasian wewenang serta desentralisasi peran pada institusi local (missal: kecamatan, kelurahan) juga merupakan ujud perbaikan manajemen yang mengarah pada upaya untuk memacu prestasi dan inisiatif kerja sampai di tingkat bawah. Pendelegasian wewenang akan juga berkorelasi dengan upaya pengembangan kompetensi manajerial, yang salah satu bentuknya adalah pengembangan kompetensi kepemimpinan. Mengutip ungkapan dari seorang partisipan, "Leadership itu kalau saya intinya harus mendengar, tapi setelah mendengar harus berani ambil kebijakan. Kebijakan itu ada yang pro dan kontra, jadi ada yang setuju dan tidak setuju. Saya (harus) menyikapi itu, baru nanti ada perbaikanperbaikan".

\section{Pengembangan Perekonomian}

Era globalisasi harus dimanfaatkan sebagai kesempatan untuk mengembangkan perekonomian daerah. Daerah harus mampu mempromosikan dan sekaligus menjual potensi dan program kebijakan kerjanya sehingga tercipta jarring hubungan yang menguntungkan. Hal ini tentunya akan berdampak positif pada upaya peningkatan perekonomian.

Penanaman modal di bidang pariwisata nampak merupakan salah satu pilihan yang cukup strategis untuk dikembangkan lebih jauh, mengingat potensinya yang cukup besar. Untuk itu, promosi pariwisata ke daerah-daerah lain di Indonesia maupun mancanegara menjadi pilihan strategis. Seorang partisipan berpendapat, "Bahwa untuk pengembangan pariwisata, dana-dana yang kita dapat dari masyarakat kita kembalikan lagi (dalam bentuk) promosi, karena seandainya masyarakat luar daerah dan luar negeri itu semakin banyak masuk, maka otomatis juga akan bisa membantu pendapatan mereka; mungkin akan membuka kesempatan kerja yang lebih luas".

\section{Peningkatan Kualitas SDM}

Globalisasi, yang notabene berarti meluasnya lingkup aktivitas organisasi, menuntut dikembangkannya kualitas SDM. Kualitas SDM yang 
tinggi mempunyai peran yang strategis dalam menghadapi luasnya tantangan dan tuntutan lingkungan yang harus dihadapi oleh organisasi Pemda.

Berkembangnya teknologi informasi sebagai sarana komunikasi misalnya, menuntut individu pekerja untuk mampu mengembangkan kompetensinya dalam bidang teknologitersebut. Demikian juga dengan bervariasinya tuntutan masyarakat terhadap kualitas kinerja Pemda. Hal ini menuntut individu untuk berperilaku kreatif dan fleksibel. Mereka pada prinsipnya dituntut untuk bersikap luwes, kreatif, dan kompeten dalam bidang kerjanya.

Menyitir pendapat salah sorang partisipan, "Peningkatan kinerja pegawai ada di pengembangan, (yang) salah satunya adalah upaya (peningkatan) kemampuan aparat (agar bisa) mengikuti tuntutan keadaan".

\section{Perubahan Mindset}

Terdapat beberapa tema pokok yang berkaitan dengan perubahan mindset atau cara pandang individu, yaitu: (1) sikap dan jiwa kewirausahaan dalam bekerja; (2) mengikis habis mental birokrat; (3) pengembangan dan pemahaman visi yang sama dalam mengemban tugas; serta (4) mampu menerima dan bersikap terbuka terhadap perubahan-perubahan yang terjadi di organisasi.

Sikap kewirausahaan perlu dikembangkan untuk menggantikan sikap-sikap sebagai birokrat, mengingat otda dan globalisasi mengarah pada pola tuntutan masyarakat yang serba berubah. Dengan makin terbukanya informasi di kalangan masyarakat menyebabkan tuntutan masyarakat berkembang semakin kompleks. Cara-cara kerja yang baku dan birokratis seringkali tidak cukup efektif untuk dikembangkan. Pekerja harus mampu menggunakan kreativitasnya untuk mencari terobosan-terobosan yang mampu difungsikan sebagai sarana pemenuhan kebutuhan masyarakat.

Walaupun sikap-sikap kewirausahaan yang bertumpu pada kompetensi kreatif sangat diperlukan, namun pengembangan visi yang sama dalam bekerja tetap diperlukan. Dalam hal ini, pimpinan wajib mensosialisasikan visi Pemda pada para karyawannya sehingga tercapai satu cara pandang dan perilaku kerja yang sinergis. Pimpinan harus mampu berfungsi sebagai lokomotif yang mampu menggerakkan dan mengarahkan kinerja gerbong-gerbong karyawannya.

Dari uraian ini dapat disimpulkan bahwa perubahan cara pandang harus difungsikan dalam pemahaman aparat Pemda sebagai pelayan masyarakat, bukan sebagai birokrat yang harus dilayani. Ini berarti otonomisasi dan globalisasi menciptakan tuntutan-tuntutan agar individu pekerja dan masyarakat mau berubah, mau menyesuaikan pengetahuan, kemampuan, sikap, serta arah kerjanya sesuai dengan tuntutan-tuntutan masyarakat yang terus berkembang. Keteguhan dalam menerjemahkan visi or- 
ganisasi akan sangat besar pengaruhnya terhadap keberhasilan Pemda menghadapi tuntutan-tuntutan itu. Visi yang sama akan membuat kerja individu menjadi satu kesatuan yang sinergis.

\section{MODEL TEORETIS STRATEGI PEMERINTAH DAERAH}

Atas dasar informasi yang tertuang pada Tabel I, kategori-kategori yang ada kemudian diseleksi dan dianalisis kembali untuk dicari keterkaitannya antara satu dengan yang lain. Hal ini dilakukan dengan cara mengkaji kembali kategori-kategori itu dengan cara pandang baru, sehingga bisa diketahui bagaimana konteks yang melatarbelakangi dikembangkannya suatu jenis strategi, variabel intervening yang memfasilitasi munculnya strategi tersebut, serta bagaimana konsekuensi dari dikembangkannya strategi itu. Cara ini merupakan pengejawantahan dari axial coding dan selective coding sebagai prosedur analisis dan interpretasi data (Strauss \& Corbin, 1990).

Dari Gambar 1 (Gambar 1: Model Teoritis Strategi Pemda dalam Menghadapi Era Otonomi Daerah dan Globalisasi) dapat dilihat keberadaan dan fungsi Pemda saat ini nampak dalam proses menuju perubahan. Hal ini terutama disebabkan oleh munculnya Undang-Undang Otonomi Daerah. Pemda yang tadinya merupakan organisasi yang fungsinya tergantung pada Pemerintah Pusat, berubah menjadi organisasi yang otonom. Diberlakukannya Undang-Undang tersebut jelas membawa dampak yang luas pada bagaimana Pemda dipersepsikan oleh masyarakat, bagaimana persepsi internal pegawai Pemda sendiri terhadap perubahan fungsi tersebut, serta bagimana pola hubungan Pemda dengan Pemerintah Pusat.

Situasi tersebut jelas akan sangat mempengaruhi strategi yang harus dikembangkan. Pemda, dalam hal ini, perlu mengembangkan strategi yang tepat, baik secara organisasional maupun individual, sesuai dengan perubahan yang dihadapi serta konteks yang mempengaruhinya. Globalisasi, perkembangan teknologi informasi dan komunikasi (misal: internet), serta perubahan visi dan misi haruslah dijadikan bahan pemikiran bagi upaya pengembangan strategi.

Memahami hal tersebut, Pemda mau tidak mau harus menempatkan upaya pemberdayaan masyarakat sebagai strategi utama dalam menyikapi perubahan situasi serta diberlakukannya Undang-Undang Otonomi Daerah. Melalui upaya pemberdayaan, masyarakat diajak berpartisipasi dan bekerja sama untuk memanfaatkan segala potensi daerah sehingga paling tidak perekonomian daerah mampu bergeliat dan tumbuh. Selain itu, proses pemberdayaan diarahkan pula pada upaya untuk menciptakan komponen masyarakat yang berwawasan entrepreneur. 


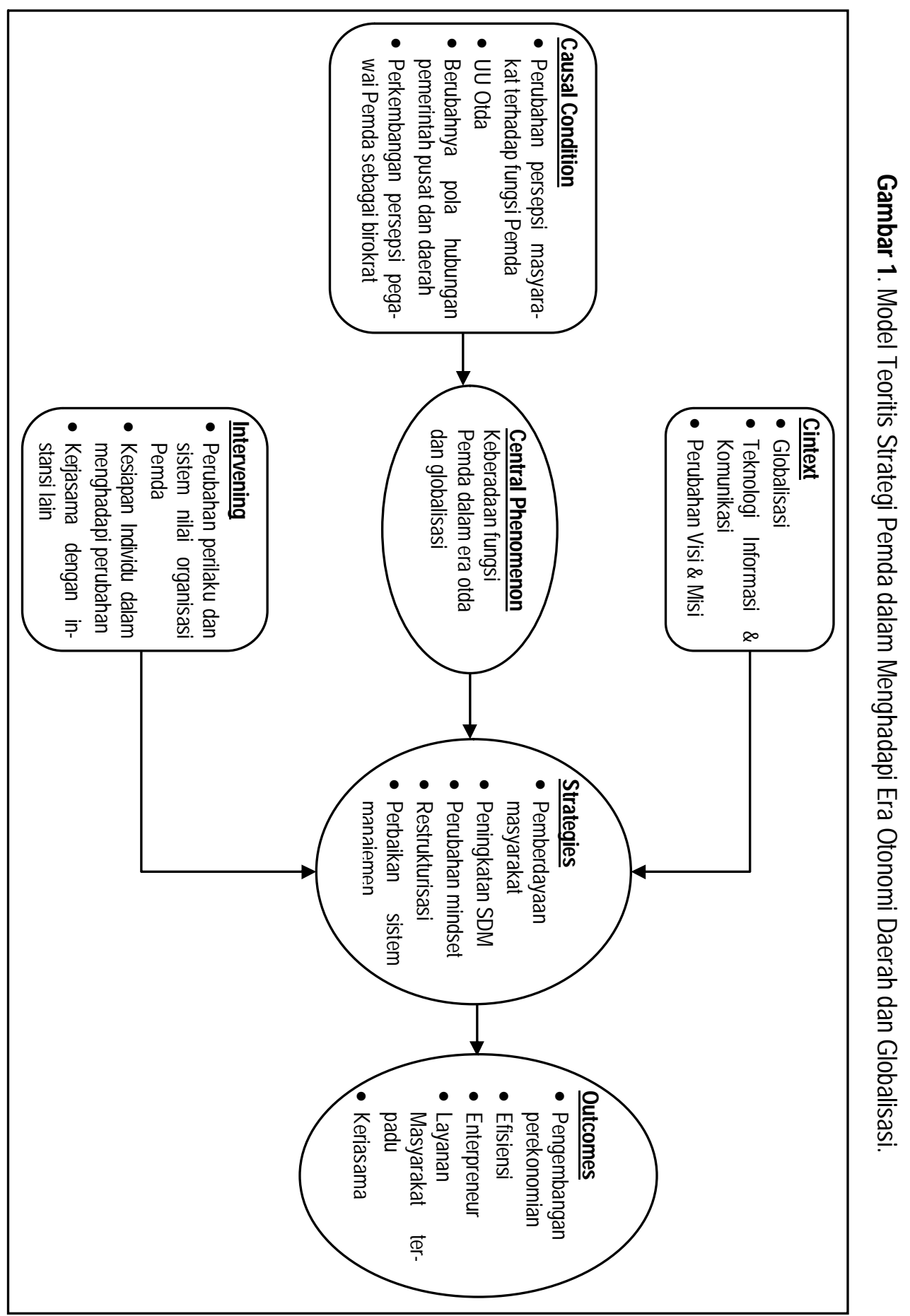


Untuk mencapai tujuan itu efisiensi perlu diciptakan dengan meningkatkan fungsi-fungsi internal dari organisasi Pemda, seperti: peningkatan kualitas SDM, perubahan mindset, perampingan struktur, serta perbaikan sistem manajemen secara umum. Dengan cara demikian maka Pemda akan mampu berfungsi efisien dan menghasilkan kualitas layanan yang prima, yang sesuai dengan perkembangan tuntutan dan kebutuhan masyarakat dan lingkungan.

Agar mampu memfungsikan strategi tersebut secara optimal sehingga mampu menghasilkan keluaran seperti yang direncanakan, Pemda perlu memperhatikan beberapa variabel yang berpengaruh. Variabelvariabel tersebut meliputi: perubahan iklim dan budaya organisasi, kesiapan individu dalam menghadapi perubahan, serta efektivitas kerja sama dan networking yang dikembangkan. Dengan mengintegrasikan variabelvariabel ini dalam strategi organisasi, maka fungsi Pemda akan lebih optimal.

Dari hasil penelitian terlihat bahwa dalam menghadapi situasi yang serba berubah, Pemda melakukan dua strategi pokok, yaitu: (1) maintaining the current system (fungsi pemeliharaan); dan (2) adaptation (fungsi penyesuaian diri dengan lingkungan).

Upaya pemeliharaan fungsi sitem organisasi nampak dari restrukturisasi, perbaikan sistem manajemen, peningkatan kualitas SDM, serta perubahan mindset. Upaya-upaya strategis ini diarahkan pada usaha untuk memelihara sekaligus memperkuat fungsi-fungsi internal organisasi sehingga organisasi tetap mampu menjalakan aktifitas rutin sehari-hari (i.e. memelihara kondisi yang stabil). Tanpa upaya ini jelas otda akan berakibat pada macetnya segala fungsi internal organisasi, dan Pemda tidak akan mampu, misalnya, memberikan layanan rutin pada masyarakatnya. Strategi adaptasi, di lain fihak, terlihat dari upaya-upaya pemberdayaan masyarakat dan pengembangan perekonomian daerah. Hal ini dilakukan dengan mengembangkan keterkaitan fihak luar untuk mau berinvestasi di Daerah Istimewa Yogyakarta (DIY). Upaya adaptasi ini berfungsi untuk mengembangkan hubungan dan menyesuaikan diri dengan tuntutan lingkungan luar.

Pengembangan dua strategi tersebut selaras dengan hasil penelitian Himam (2002) yang menemukan reaksi pemeliharaan dan adaptasi merupakan dua pola pokok perilaku organisasi dalam menghadapi situasi yang berubah. Dalam hal ini, strategi pemeliharaan berfungsi untuk menciptakan support system yang mampu menjaga kesinambungan fungsi organisasi, serta menciptakan momentum untuk melakukan adaptasi.

Ahli lain, Cross dan Smith (1996), melihat fenomena adaptasi (contoh: pemberdayaan masyarakat, menarik investor) sebagai upaya untuk menciptakan customer bonding. Artinya, dengan dilibatkannya 
masyarakat dan investor dalam mengelola potensi sumberdya daerah yang ada, secara langsung Pemda menciptakan semacam keterikatan yang dilandasi oleh perasaan saling diuntungkan. Keterikatan ini akan membuat hubungan Pemda dengan masyarakat dan investor menjadi berlanjut.

Hal yang senada juga dikemukakan oleh Carnall (1990) yang menjelaskan mengenai fase pengembangan strategi dalam menghadapi perubahan. Secara umum fase ini meliputi upaya: (1) sustaining organizational effectiveness, yang dalam hal ini relevan dengan strategi restrukturisasi; (2) creating acceptance to change. Strategi Pemda yang sejalan dengan konsep ini adalah perubahan mindset melalui upaya pengikisan mental birokrat serta membuka jalur informasi melaui penggunaan teknologi informasi dan komunikasi; (3) managing change. Pemda melakukannya melaui upaya peningkatan kualitas SDM serta perbaikan sistem manajemen; dan (4) coping with change, yang antara lain dilakukan dengan cara merangsang berkembangnya partisipasi masyarakat untuk turut berkiprah dalam mengelola sumberdaya daerah.

\section{KESIMPULAN}

Dengan menganalisis dan mensintesiskan hasil dan pembahasan penelitian, maka dapat disimpulkan bahwa strategi Pemda dalam era otonomi daerah dan menanggapi arus globalisasi mencakup dua hal pokok, yaitu:

1. Strategi yang mengarah pada upaya pemeliharaan fungsi sistem yang ada. Strategi ini meliputi upaya-upaya restrukturisasi, perbaikan sistem manajemen, peningkatan kualitas SDM, dan perubahan pola fakir (mindset) dari para aparatnya. Strategi ini berfungsi untuk menjaga kesinambungan kerja organisasi, sehingga walupun situasi yang dihadapi Pemda berubah dan Pemda masih dalam prose penyesuaian diri dengan perubahan ini, tapi sebagai satu institusi masih tetap mampu menghasilkan keluaran yang diharapkan masyarakat;

2. Strategi yang mengacu pada upaya adaptasi terhadap perubahan tuntutan lingkungan. Strategi ini meliputi: pemberdayaan masyarakat serta pengembangan perekonomian daerah. Melalui strategi ini diharapkan Pemda mampu merangsang partisipasi msyarakat serta mampu menarik minat investor untuk berinvestasi di DIY.

\section{SARAN}

Dari kesimpulan di atas, disarankan untuk:

1. Dilakukan penelitian lanjutan yang sifatnya kuantitatif untuk memvalidasi serta mengkaji kemungkinan generalisasi hasi bila hasil penelitian 
ini akan digunakan untuk memprediksi strategi-strategi yang dikembangkan Pemda-Pemda lain di Indonesia;

2. Karena keterbatasan waktu dan akses ke Pemda, upaya uji validitas hasil penelitian ini masih terbatas pada uji validitas internal yang dilakukan melalui konsistensi interpretasi hasil penelitian pada tiga peneliti. Oleh karenanya, disarankan, pada penelitian lanjutan, melibatkan partisipan penelitian untuk mengkaji kesimpulan-kesimpulan penelitian yang dihasilkan (i.e. upaya triangulasi);

3. Sebagai tindak lanjut, hasil penelitian ini dapat diterjemahkan dalam bentuk-bentuk pengembangan organisasi Pemda yang lebih konkret. Untuk itu diperlukan kerja sama lebih lanjut dengan fihak Pemda untuk mewujudkan hasil-hasil penelitian ini ke dalam bentuk-bentuk program pelatihan dan konsultasi.

\section{DAFTAR PUSTAKA}

Bogdan, L.C., \& Biklen, S.K. (1992). Qualitative research in education: an introduction to theory and methods. Boston: Allyn \& Bacon.

Cady, S.H., \& Hardalupas, L. (1999). A lexicon for organizational change: examining the use of language in popular, practitioner, and scholar periodicals. The Journal of Applied Business Research, 15(4), 8194.

Carnall, C.A. (1990). Managing change in organizations. New York: Prentice-Hall.

Carnevale, A.P. (1991). American and the new economy. Washington, D.C.: The Labor Society for Training and Development, and U.S. Department of Labor.

Clute, P.W., Clute, P., \& Associates. (1999). Change at oil refinery: toward the creation of a learning organization. Human Resources Planning, 22(2), 24-38.

Creswell, J.W. (2002). Educational research: planning, conducting, and evaluating qualitative and quantitative research. Colombus, $\mathrm{OH}$ : Merrill Prentice Hall.

Cross, R. \& Smith, J. (1996). Customer bonding: Pathway to lasting customer loyalty. Lincolnwood, IL: NTC Business Books.

Das, T.K. (1995). Managing strategic flexibility: key to effective performance. Journal of General Manegement, 20(3), 60-75. 
DiBella, A.J. (1993). The role of assumptions in implementing management practices across cultural boundaries. The Journal of Applied Behavioral Sciences, 29(3), 311-327.

Gowing, K.F., Kraft, J.D., \& Quick, J.C. (1998). The new organization reality: downsizing, restructuring, and revitalization. Washington, D.C.: American Psychological Association.

Herscovitch, L., \& Meyer, J.P. (2002). Commitment to organizational change: extension of three-component model. Journal of Applied Psychology, 87(3), 474-487.

Himam, F. (1996). Explaining change in organization: a grounded theory study of how the Housing Department of the University of Nebraska-Lincoln experiences change (research project, University of Nebraska-Lincoln, USA).

---------. (2002). Inventing the future: a meta-ethnographic analysis towards understanding the process of individual and organizational adaptive strategies to change (dissertation, University of Nebraska-Lincoln, USA).

Lazlo, C., and Laugel, J-F. (2000). Large-scale organizational change: An Executive's guide. Boston, Massachusetts: ButterworthHeinemann.

Nevis, E.C., DiBella, A.J., \& Gould, J.M. (1995). Understanding organizations as learning systems. Sloan Management Review, Winter, 7385.

Stake, R.E. (1995). The art of case study research. Thousand oaks, CA: Sage Publications.

Stickland, F. (1998). The dynamics of change: insights into organizational transition from the natural world. London: Routlege.

Strauss, A.L., \& Corbin, J. (1990). Basics of qulaitative research: grounded theory procedures and technique. Newbury Park: Sage Publications.

Van de Ven, A.H., \& Poole, M.S. (1995). Explaining development and change in organization. Academy of Management Review, 20(3), 510-540. 


\section{BIODATA PENULIS}

Fathul Himam, adalah dosen Fakultas Psikologi UGM. la menyelesaikan S1 pada Fakultas Psikologi UGM (1983), menyelesaikan S2 (MSi) pada Fakultas Psikologi UI (1988) dan MA pada University of IOWA (1991). Gelar PhD diperolehnya di University of Nebraska (2002) dengan disertasi berjudul "Inventing The Future: A MetaEthnographic Analysis Towards Understanding The Process of Individual and Organizational Adaptive Strategies to Change".

Bagus Riyono, adalah dosen Fakultas Psikologi UGM. la menyelesaikan S1 pada Fakultas Psikologi UGM (1991), dan menyelesaikan S2 (MA) pada Industrial and Organizational Psychology Department, Hofstra University, New York (1999).

Sumaryono, adalah dosen Fakultas Psikologi UGM. Ia menyelesaikan S1 pada Fakultas Psikologi UGM (1991), dan menyelesaikan S2 (MSi) pada Fakultas Psikologi UGM (2001). Saat ini sedang menempuh Program Doktor Psikologi pada Program Pasca Sarjana Psikologi UGM. 